\title{
Selection of breeding stock in pigs favours 6PGD heterozygotes
}

\author{
JEFFRY B. MITTON ${ }^{*}$, DANIEL J. ZELENKA $\ddagger \&$ PATRICK A. CARTER $\dagger$ \\ $\dagger$ Department of Environmental, Population and Organismic Biology, University of Colorado, Boulder, CO 80309 and \\ $\ddagger$ Tyson Foods Inc., Springdale, AR 72765-2020, U.S.A.
}

\begin{abstract}
Associations between genetic variation at four enzyme polymorphisms and growth rate, feed conversion and economic index were studied in commercial lines of pigs. These lines were also tested for the fit of observed genotypic frequencies to expected genotypic frequencies at the four polymorphic loci. Genotypic distributions fit Hardy-Weinberg expectations in four pure-breeding lines but crosses among lines produced excesses in heterozygosity at the locus coding for 6-phosphogluconate dehydrogenase $(6 P G D)$ due to differences in allelic frequencies among lines. Selection of breeding individuals further enhanced the heterozygosity at $6 P G D$ to 73-93 per cent but it had no impact on a linked locus that was sometimes in linkage disequilibrium with $6 P G D$. The relationship between feed conversion and individual heterozygosity was examined in one population sample; feed conversion increased with individual heterozygosity.
\end{abstract}

Keywords: allozymes, artificial selection, feed conversion, growth rate, linkage disequilibrium, pigs.

\section{Introduction}

Darwin (1859) gained considerable insight into the mechanisms of natural selection from his observations of artificial selection in populations of domesticated plants and animals. Similarly, Fisher (1930), Haldane (1932) and Wright (1977) combined studies from plant and animal breeding with studies of natural populations to learn more about genetics and evolution. Recently, studies of demographic and physiological variation in natural populations have raised important questions for both evolutionary biologists and plant and animal breeders. In studies which combine genetic and demographic data and in studies which combine genetic and physiological data, there are often, but certainly not always, relationships between genotype and measures of performance. Many of these studies report estimates of fitness or performance associated with single locus and multilocus heterozygosity of enzyme polymorphisms (Mitton \& Grant, 1984; Allendorf \& Leary, 1986; Ledig, 1986; Zouros \& Foltz, 1987; Mitton, 1993a). For example, comparisons among life-history stages or among age classes typically reveal viability differentials associated with allozyme genotypes. Viability differs among allozyme genotypes in Avena barbata (Clegg \& Allard, 1973),

*Correspondence.
Hordeum vulgare (Clegg et al., 1978), Lolium multiflorum (Mitton, 1989), Mytilus edulis (Koehn et al., 1976), Crassostrea virginica (Singh, 1982; Zouros et al., 1983), Macoma balthica (Green et al., 1983), Fundulus heteroclitus (Mitton \& Koehn, 1975; Mitton, 1993a), Poecilia reticulata (Beardmore \& Shami, 1979) and Colias eriphyle (Watt, 1983; Watt et al., 1983). Growth rate is associated with allozyme genotype in Crassostrea virginica (Zouros et al., 1980), Mytilus edulis (Koehn \& Gaffney, 1984), Ambystoma tigrinum (Pierce \& Mitton, 1982), Populus tremuloides (Mitton \& Grant, 1980), Mulinia lateralis (Koehn et al., 1988) and white-tailed deer, Odocoileus virginianus (Cothran et al., 1983). These associations have inspired further genetic and physiological studies designed to understand better the links between enzyme genotype and measures of whole plant or animal physiology. Such studies have revealed associations between allozyme genotype and oxygen consumption in Crassostrea virginica (Koehn \& Shumway, 1982; Rodhouse \& Gaffney, 1984), Thais hemostomata (Garton, 1984; Garton et al., 1984), Mytilus edulis (Diehl et al., 1985, 1986), Salmo gairdneri (Danzmann et al. 1987) and Ambystoma tigrinum (Mitton et al., 1986). Rates of protein turnover and routine metabolic costs differ among allozyme genotypes in Mytilus edulis and this relationship may drive the correlations between allozyme heterozygosity and oxygen consumption, growth rate and viability (Hawkins et al., 1986, 1989). 
It is difficult to determine whether the correlations listed above are directly attributable to the enzymes that are used as genetic markers or whether the differences are attributable to associated regulatory loci, other genes in linkage disequilibrium with the marker loci or to variation in levels of inbreeding that are reflected in individual heterozygosity. If some of the physiological and demographic variation is directly attributable to genetic variation of enzymes, these loci might contribute to the phenomena of heterosis, inbreeding depression and genetic homeostasis (Lerner, 1954; Mitton 1993a,b). If the protein polymorphisms have no direct impact on physiology and are simply linked to and in linkage disequilibrium with loci influencing components of fitness, then the correlations should diminish as linkage disequilibrium decays. If the protein polymorphisms are selectively neutral but inadvertently reflect levels of inbreeding, then the correlations should decline to zero in uniformly outcrossed populations. In any of these cases, protein polymorphisms are useful markers but if protein polymorphisms directly influence physiology and demography, they will be especially important to evolutionary biologists and plant and animal breeders.

The objective of this study was to determine whether protein genetic markers were correlated with measures of performance that are of direct interest to breeders or whether established selection programmes select for specific genotypes. We looked for associations between enzyme genotypes and growth rate, feed conversion and economic index in four population samples of pigs, Sus scrofa domestica, from a production facility. We also tested for differences in genotypic frequencies between selected and nonselected groups of pigs. Our results suggest that enzyme markers might be useful in breeding programmes.

\section{Materials and methods}

The pigs utilized in this study were from commercial lines maintained on farms near Springdale, AR. Each individual was weighed at approximately 107 and 170 days and the difference between the weights divided by the number of days between weighings was used as an estimate of growth rate (GR). Feed conversion (FC), the ratio of feed consumed to the weight gained, was obtained on full sibs, penned in groups of three. Because the influence of family genotype was confounded with allozyme genotype, the relationship between genotype and FC was not analysed when FC was measured this way. However, in group 4, described below, gilts, or females that had not produced a litter, were penned in groups of three, solely by G6PD genotype. Gilts were sampled from 80 families, so the probability of being penned with a full sib was very low; the relationship between $\mathrm{FC}$ and genotype was examined in this group. Index (IN) is an estimate of the economic value of an individual and it is a function of lean growth and family feed conversion.

Terminal sires and dams are used as production parents and as breeding adults they produce the market animal. Each terminal parent is an $F_{1}$ produced by a cross between pure lines. Terminal sires are produced by crossing males from a Duroc line (D) with females from a Large White line (B). Selection pressure on these lines emphasizes lean growth rate and meat quality. Dams are produced by crossing males from a Landrace line $(\mathrm{C})$ with females from a Large White line (A) with emphasis on the number of pigs/sow/year. Individuals genotyped from lines A, B, C and D were a random sample of those available.

Four population samples were taken from the terminal sire production line $(\mathrm{D}$ sire $\times \mathrm{B}$ dam). Three groups contained only males (groups 1, 2 and 3); these males were not a random sample but were those selected at 107 days of age as possible breeder replacement stock. Group 4 contained only females, selected on the basis of general condition and G6PD genotype, for a study of feed conversion. In groups 1-3, 66, 65 and 57 individuals were sampled from 22, 16 and 15 families, respectively. In group 4, 132 individuals were sampled from 80 families.

Whole blood $(3-5 \mathrm{ml})$ from individual pigs was taken into a vacutainer containing an EDTA solution to prevent coagulation. Blood samples were shipped from Springdale, AR, in refrigerated containers to the University of Colorado where they were centrifuged at $3000 \mathrm{~g}$ at $10^{\circ} \mathrm{C}$ for $5 \mathrm{~min}$ to pack down red blood cells. The serum layer was used for electrophoresis of prealbumins (PA). Packed red blood cells were mixed with an equal volume of homogenation buffer $(0.1 \mathrm{M}$ Tris$\mathrm{HCl} \mathrm{pH} \mathrm{8.0,0.01} \mathrm{м} \mathrm{NADP,} 0.01 \mathrm{~m}$ dithiothreitol) and vortexed for $10 \mathrm{~s}$ to lyse red blood cells. This homogenate was loaded into horizontal starch gels to resolve enzyme polymorphisms for phosphoglucose isomerase (PGI), 6-phosphogluconate dehydrogenase (6PGD) and glucose-6-phosphate dehydrogenase (G6PD). PGI ran cathodally and 6PGD ran anodally on the Triscitrate buffer system of Tanaka et al. (1980). G6PD was resolved on the sodium phosphate buffer system of Bengtsson \& Sandberg (1973). PA were resolved on vertical acrylamide electrophoresis with a stacking gel of 8 per cent acrylamide and a running gel of 14 per cent acrylamide, after Gahne et al. (1977).

$P G I$ and $6 P G D$ are approximately $8.5 \mathrm{cM}$ apart on chromosome 15 (Rasmussen, 1983). These genes are linked to $\mathrm{Hal}$, a gene which influences calcium channels and has a substantial impact on meat quality 
(Rasmussen, 1983) but $\mathrm{Hal}$ genotypes were not examined in this study. G6PD is on the X chromosome and $P A$ is on chromosome 5 (Echard, 1984).

A double-blind experiment was conducted to examine the relationship between genotype and feed conversion in group 4. A total of 183 females were surveyed for their G6PD genotypes. Blood samples were shipped from Tyson Foods, Inc. to the University of Colorado where the samples were genotyped for the four polymorphic loci. Numbers on the blood vials were returned to Tyson Foods in three groups, corresponding to, but not revealing, G6PD genotypes. On the basis of G6PD genotype and general condition, 135 individuals were included in the study, with individuals of like genotype penned together to estimate feed conversion. 6PGD genotypes were then compared between the group selected for this experiment and the group eliminated from the experiment. Complete data could not be obtained for three of the 135 animals in the test and genotypic data were analysed for only those individuals for which complete data were available. Consequently, the sample sizes in group 4 of Table 3 are not always divisible by three.

Single classification analysis of variance was used to test for differences among alternate genotypes at each locus in growth rate and index. Multilocus genotypes were summarized as individual heterozygosity (Mitton \& Pierce, 1980), the number of loci heterozygous per individual, which varied from zero to four in these samples. Spearman's rank order correlation coefficient was used to test for a correlation between individual heterozygosity and feed conversion in group 4 . Heterogeneity of allelic frequencies was tested with the $\chi^{2}$ test described by Workman \& Niswander (1970). The fit of genotypic frequencies to those expected under the assumptions of the Hardy-Weinberg equilibrium was tested by a $\chi^{2}$ test as described by Spiess (1977). Linkage disequilibrium was tested from dilocus genotypic data by the maximum-likelihood method of Webster (1979).

\section{Results}

Twenty-eight enzyme loci were surveyed for genetic variation, revealing polymorphisms at $P G I, G 6 P D$ and $6 P G D$. In addition, proteins in serum were examined for variation, revealing a polymorphism at $P A$. Two alleles were segregating at each of the polymorphic loci. The allelic frequencies of $P A$ were heterogeneous among the four groups, with the frequency of the faster migrating allele ranging from 0.35 to $0.52(P<0.05$, Table 1). Allelic frequencies were homogeneous among the four groups for $P G I$ (Table 2). The frequencies of $G 6 P D$ were heterogeneous, with the frequency
Table 1 Allelic and genotypic frequencies for prealbumin $(P A)$ in four samples of pigs

\begin{tabular}{crrrccr}
\hline \multicolumn{7}{c}{ Genotypes } \\
\cline { 2 - 6 } Group & \multicolumn{1}{c}{11} & 12 & 22 & $p \pm \mathrm{SE}$ & $\chi_{\mathrm{a}}^{2}$ & \multicolumn{1}{c}{$F$} \\
\hline 1 & 6 & 43 & 17 & $0.42 \pm 0.043$ & $7.6^{* *}$ & -0.340 \\
2 & 9 & 28 & 29 & $0.35 \pm 0.041$ & 0.3 & 0.066 \\
3 & 15 & 30 & 13 & $0.52 \pm 0.046$ & 0.1 & -0.036 \\
4 & 18 & 65 & 49 & $0.38 \pm 0.030$ & 0.2 & -0.042 \\
& & \multicolumn{5}{c}{$\chi_{\mathrm{b}}^{2}=8.4^{*}$} \\
\hline
\end{tabular}

$* P \leqslant 0.05,{ }^{* *} P \leqslant 0.01,{ }^{* * *} P \leqslant 0.001$.

$p$ is the frequency of allele no. 1 and $F$ is the inbreeding coefficient.

$\chi_{\mathrm{a}}^{2}$ tests the fit of the genotypic distribution to the distribution expected at the Hardy-Weinberg equilibrium.

$\chi_{\mathrm{b}}^{2}$ tests the heterogeneity of allelic frequencies among the population samples.

Table 2 Allelic and genotypic frequencies for phosphoglucose isomerase $(P G I)$ in four samples of pigs

\begin{tabular}{|c|c|c|c|c|c|c|}
\hline \multirow[b]{2}{*}{ Group } & \multicolumn{3}{|c|}{ Genotypes } & \multirow[b]{2}{*}{$p \pm \mathrm{SE}$} & \multirow[b]{2}{*}{$\chi_{\mathrm{a}}^{2}$} & \multirow[b]{2}{*}{$F$} \\
\hline & 11 & 12 & 22 & & & \\
\hline 1 & 2 & 15 & 49 & $0.14 \pm 0.031$ & 0.1 & 0.056 \\
\hline 2 & 0 & 27 & 39 & $0.20 \pm 0.035$ & 1.60 & -0.257 \\
\hline 3 & 0 & 17 & 41 & $0.15 \pm 0.033$ & 0.5 & -0.172 \\
\hline 4 & 2 & 33 & 97 & $0.14 \pm 0.021$ & 0.1 & -0.037 \\
\hline \multicolumn{7}{|c|}{$\chi_{\mathrm{b}}^{2}=3.10$} \\
\hline
\end{tabular}

See footnote in Table 1.

of the faster migrating allele varying from 0.18 to 0.46 $(P<0.001$, Table 3). Allelic frequencies of $6 P G D$ were homogeneous among the four groups (Table 4).

Genotypic frequencies at $P A$ approximated equilibrium frequencies in three of the population samples but an excess of heterozygotes was observed in group 1 (Table 1, $P<0.01$ ). Genotypic distributions at $P G I$ approximated equilibrium expectations in all four population samples (Table 2). G6PD is sex-linked, so there was no test for genotypic proportions for groups 1,2 and 3, which were all males. In group 4 , which was all females, there was a significant excess of heterozygotes for $G 6 P D(P<0.05$, Table 3$)$.

Highly significant excesses of heterozygotes were found in each of the four groups for $6 P G D$ when they were tested against Hardy-Weinberg expectations $\left(E_{1}\right.$, $P \ll 0.001$, Table 4). The proportions of heterozygotes in these groups of individuals selected for breeding ranged from 73 per cent (group 1) to 93 per cent 
(group 3). Each of these groups was produced by a cross between lines and excesses of heterozygotes were expected if males and females differed in allelic frequencies. The allelic frequencies were heterogeneous among the lines that produced these groups (Table 5);

Table 3 Allelic and genotypic frequencies for glucose-6phosphate dehydrogenase $(G 6 P D)$ in four samples of pigs

\begin{tabular}{|c|c|c|c|c|c|c|}
\hline \multirow[b]{2}{*}{ Group } & & \multicolumn{3}{|c|}{ Haplotypes } & \multirow{2}{*}{\multicolumn{2}{|c|}{$p \pm \mathrm{SE}$}} \\
\hline & & \multicolumn{2}{|c|}{1} & 2 & & \\
\hline 1 & & \multicolumn{2}{|c|}{24} & 42 & \multicolumn{2}{|c|}{$0.36 \pm 0.059$} \\
\hline 2 & & \multicolumn{2}{|c|}{30} & 35 & \multicolumn{2}{|c|}{$0.46 \pm 0.062$} \\
\hline \multirow[t]{3}{*}{3} & & \multicolumn{2}{|c|}{10} & 47 & \multicolumn{2}{|c|}{$0.18 \pm 0.051$} \\
\hline & \multicolumn{3}{|c|}{ Genotypes } & & \multirow[b]{2}{*}{$\chi_{\mathrm{a}}^{2}$} & \multirow[b]{2}{*}{$F$} \\
\hline & 11 & 12 & 22 & $p \pm \mathrm{SE}$ & & \\
\hline 4 & 3 & 61 & 68 & $0.25 \pm 0.027$ & $6.4^{*}$ & -0.22 \\
\hline \multicolumn{7}{|c|}{$\chi_{b}^{2}=16.44^{* * *}$} \\
\hline
\end{tabular}

See footnote in Table 1.

$G 6 P D$ is sex-linked.

Haplotypes are presented for the first three groups, which are all males.

Genotypes are presented for group 4, which is all gilts. the frequency of the faster allele was 0.71 in line $\mathrm{B}$ and 0.10 in line D. A cross between these lines was expected to produce 67 per cent heterozygotes. When the expected genotypic proportions were adjusted to account for the differences in allelic frequencies in strains B and D ( $E_{2}$ in Table 4), group 1 did not depart from expectations but group 2 was at the borderline of statistical significance and groups 3 and 4 deviated from expectations, all with excesses of heterozygotes. Combining the probabilities from these tests of significance (Sokal \& Rohlf, 1981) yielded a $\chi^{2}$ value of 29.6 $(P<0.001)$, indicating a significant excess of heterozygotes across all groups. Thus, the differences in allelic frequencies among lines are not sufficient to produce the excesses of heterozygotes in Table 4 . Excesses of heterozygotes appear in animals selected for breeding (Table 4) but they are not detected in random samples from the pure lines (Table 5). The selection imposed on the groups for breeder replacement favoured 6PGD heterozygotes.

Direct evidence that selection favours 6PGD heterozygotes was found in group 4 , which was originally examined for a study of the relationship between G6PD genotypes and feed conversion. The consequences of this selection are illustrated in Table 6, which presents the 6PGD genotypes in the original sample in the selected group and the rejected group. Seventy per cent of the original sample was hetero-

Table 4 Allelic and genotypic frequencies for 6-phosphogluconate dehydrogenase $(6 P G D)$ in four samples of pigs

\begin{tabular}{|c|c|c|c|c|c|c|c|}
\hline \multirow[b]{2}{*}{ Group } & \multicolumn{4}{|c|}{ Genotypes } & \multirow[b]{2}{*}{$p \pm \mathrm{SE}$} & \multirow[b]{2}{*}{$\chi_{\mathrm{a}}^{2}$} & \multirow[b]{2}{*}{$F$} \\
\hline & & 11 & 12 & 22 & & & \\
\hline 1 & $\begin{array}{l}E_{1} \\
E_{2}\end{array}$ & $\begin{array}{l}5 \\
(12.7) \\
(4.7)\end{array}$ & $\begin{array}{c}48 \\
(32.5) \\
(44.1)\end{array}$ & $\begin{array}{c}13 \\
(20.7) \\
(17.2)\end{array}$ & $0.44 \pm 0.043$ & $\begin{array}{l}15.0^{* * *} \\
1.4\end{array}$ & -0.476 \\
\hline 2 & $\begin{array}{l}E_{1} \\
E_{2}\end{array}$ & $\begin{array}{l}0 \\
(9.2) \\
(4.6)\end{array}$ & $\begin{array}{c}49 \\
(30.5) \\
(43.4)\end{array}$ & $\begin{array}{c}16 \\
(25.2) \\
(17.0)\end{array}$ & $0.38 \pm 0.044$ & $\begin{array}{l}23.8^{* * *} \\
5.4\end{array}$ & -0.605 \\
\hline 3 & $\begin{array}{l}E_{1} \\
E_{2}\end{array}$ & $\begin{array}{l}0 \\
(12.6) \\
(4.1)\end{array}$ & $\begin{array}{c}54 \\
(28.9) \\
(38.7)\end{array}$ & $\begin{array}{c}4 \\
(16.5) \\
(15.1)\end{array}$ & $0.47 \pm 0.046$ & $\begin{array}{l}44.0^{* * *} \\
14.2^{* * *}\end{array}$ & -0.871 \\
\hline 4 & $\begin{array}{l}E_{1} \\
E_{2}\end{array}$ & $\begin{array}{l}2 \\
(21.3) \\
(5.8)\end{array}$ & $\begin{array}{c}102 \\
(63.4) \\
(88.2)\end{array}$ & $\begin{array}{c}28 \\
(47.3) \\
(34.4)\end{array}$ & $0.40 \pm 0.030$ & $\begin{array}{c}48.8^{* * *} \\
9.2^{* *}\end{array}$ & -0.608 \\
\hline & & & & terogen & $=2.5$ & & \\
\hline
\end{tabular}

$E_{1}$ are equilibrium expectations under the assumptions of the Hardy-Weinberg law. $E_{2}$ are expectations given the allelic frequencies in lines $\mathrm{B}$ and $\mathrm{D}$ (Table 5).

$F$ is the inbreeding coefficient calculated with $E_{1}$.

$\chi_{\mathrm{a}}^{2}$ tests the fit of the observed genotypic frequency to either $E_{1}$ or $E_{2}$.

$\chi_{\mathrm{b}}^{2}$ tests the homogeneity of allelic frequencies in the four samples. 
Table 5 Allelic and genotypic frequencies for 6-phosphogluconate dehydrogenase $(6 P G D)$ in four lines of pigs

\begin{tabular}{llrrrrrr}
\hline & & \multicolumn{7}{c}{ Genotypes } & & & \\
\cline { 3 - 6 } Line & \multirow{2}{*}{ Breed } & 11 & 12 & 22 & $p \pm \mathrm{SE}$ & $\chi_{\mathrm{a}}^{2}$ & $F$ \\
\hline A & Large White & 328 & 303 & 88 & $0.67 \pm 0.012$ & 1.9 & 0.051 \\
C & Landrace & 77 & 54 & 13 & $0.72 \pm 0.026$ & 0.6 & 0.065 \\
D & Duroc & 6 & 6 & 74 & $0.10 \pm 0.023$ & $6.7^{* *}$ & 0.628 \\
B & Large White & 170 & 135 & 28 & $0.71 \pm 0.018$ & 0.0 & 0.009 \\
& & \multicolumn{7}{c}{$\chi_{\mathrm{b}}^{2}$ heterogeneity $=244.1^{* * *}$} & & \\
\hline
\end{tabular}

See footnote in Table 1.

Table 6 Allelic and genotypic frequencies for 6-phosphogluconate dehydrogenase $(6 P G D)$ in groups of pigs

\begin{tabular}{lrrrrrr}
\hline & \multicolumn{3}{c}{ Genotypes } & & & \\
Group & 11 & 12 & 22 & $p \pm \mathrm{SE}$ & $\begin{array}{c}\text { Proportion } \\
\text { heterozygotes }\end{array}$ & $F$ \\
\cline { 2 - 6 } Total & 4 & 129 & 50 & $0.37 \pm 0.025$ & 0.70 & -0.505 \\
Selected & 2 & 102 & 28 & $0.40 \pm 0.030$ & 0.77 & -0.608 \\
Rejected & 2 & 27 & 22 & $0.30 \pm 0.046$ & 0.53 & -0.251 \\
& \multicolumn{7}{c}{$\chi_{\mathrm{a}}^{2}=9.6^{* *}, \chi_{\mathrm{b}}^{2}=3.0$} & & \\
\hline
\end{tabular}

$\chi_{\mathrm{a}}^{2}$ tests the homogeneity of genotypic frequencies in the selected and rejected groups.

$\chi_{\mathrm{b}}^{2}$ tests the homogeneity of allelic frequencies in the groups.

zygous, a value consistent with that expected for a cross between lines B and D. However, 77 per cent of the selected sample was heterozygous, while 53 per cent of the rejected group was heterozygous. The values of $F$ in the selected and rejected groups were -0.608 and -0.251 , respectively. The genotypic proportions in the selected and rejected groups were significantly different (Table 6, $P<0.01$ ).

The linkage between $6 P G D$ and $P G I$ raises the possibility that genotypes at these loci would not be independently distributed. However, analyses of linkage disequilibrium revealed no consistent pattern. In groups 1 and 2, there was an excess of coupling gametes: group 1 had a value of $D=0.0509$ $\left(\chi^{2}=12.75, P<0.001\right)$ and group 2 had a value of $D=0.0697\left(\chi^{2}=18.12, P<0.001\right)$. In contrast, the values of $D$ in groups 3 and 4 were very close to zero and did not approach statistical significance.

Analyses of variance did not reveal any significant differences among PGI genotypes and GR or IN in any of the four groups. There was just one significant association between PA genotype and IN, in group 2, but because only one analysis of eight revealed a significant association, this isolated result is probably attributable to chance. There were no differences among PA genotypes for GR.

Growth rate varied among 6PGD genotypes in groups $1(P<0.05)$ and $4(P<0.001)$. However, the results of these tests are not consistent, for $6 P G D-22$ had the lowest value for GR in group 4 but the highest value in group 1 . Values of IN varied among 6PGD genotypes in group $1(P<0.01)$, with the lowest value of IN in $6 P G D-11$ and the highest value in $6 P G D-22$. The same trend was found in group $4(P<0.10)$.

Although four of the nine analyses of variance of $G 6 P D$ genotypes were statistically significant, no consistent pattern emerged. In group 4 (females), FC was highest in G6PD-12 and lowest in G6PD-11 but we were unable to test this association in the other groups (see Materials and methods). Similarly, G6PD haplotypes were associated with IN in groups 1 and 2 but the patterns were reversed in these groups. G6PD haplotypes were associated with GR in group 3 but there were no significant associations between GR and G6PD in any other group.

Feed conversion increased with heterozygosity of the four polymorphic enzyme loci in group 4. The correlation between individual heterozygosity and FC 
was $r=0.18(P<0.05)$. The values of $\mathrm{FC}$ for individuals heterozygous for $0,1,2,3$ and 4 loci (sample sizes) were $2.64(7), 2.73(33), 2.74(53), 2.78$ (33) and 2.82 (6), respectively. Individual heterozygosity was not correlated with either GR or IN in any of the groups.

\section{Discussion}

Intensively managed domesticated species are expected to retain lower levels of genetic variation than their wild progenitors, for drift is enhanced in small populations, and genetic variation can be lost in the population bottlenecks associated with the founding of new lines and selection programmes. For the same reasons, genetic variation that persists in intensively managed lines is noteworthy; although the variation may persist by chance, there is also the possibility that the artificial selection imposed on the line also serves to retain the genetic variability. The fact that variation has been maintained at the loci studied here, three of which are important in central metabolism, suggests the possibility that artificial selection has maintained these polymorphisms. In particular, the selection of animals for breeding stock is consistently reflected in the frequencies of 6PGD genotypes. This selection programme is intense; approximately 60 per cent of females and 20 per cent of males are selected for breeding. Random samples from lines A, B, C and D show no evidence of excess heterozygosity at this locus (Table 5). Genotypic distributions fit equilibrium expectations in lines $\mathrm{A}, \mathrm{B}$ and $\mathrm{C}$ and reveal a statistically significant deficiency of heterozygotes in line D. In contrast, the heterozygosities in selected groups generally exceed expectations. Selection appears to influence the maintenance of 6PGD polymorphism by dramatically increasing the frequency of heterozygotes in the animals used for breeding the market population. The degree of heterozygosity of breeding animals is especially important in a breeding programme, for the heterozygosity of parents and their offspring is correlated (Mitton et al., 1993).

The selection criteria for inclusion of animals in group 4 were undoubtedly different from the criteria used to select breeding animals. Animals were simply chosen for group 4 on the basis of size and appearance, yet this selection also favoured 6PGD heterozygotes (Table 6). This suggests either that the 6PGD variation is directly related to economic fitness or that it is in linkage disequilibrium with a locus influencing economic fitness.

The conclusion of excess heterozygosity at $6 P G D$ (Table 4) is dependent on reliable estimates of allelic frequencies in the lines crossed (Table 5) to produce these pigs. The lines were sampled at approximately the time that groups 1-4 were sampled and the sample sizes were adequate to estimate allelic frequencies $(N=86-719)$. However, we did not sample these lines repeatedly, so we do not know how stable the allelic frequencies are in time.

The measures of performance used in this study are not independent of one another. Feed conversion is used to calculate index, and weight gain is used in both the growth rate and feed conversion calculations. Therefore it is possible that there might be correlated relationships between these measures and genotype. Also, as noted in Materials and methods, some of the individuals used in this study were full sibs and therefore some of the measures of performance of the individuals are not necessarily independent of each other. However, as the numbers of families used in a domestic breeding programme is always going to be limited, this situation is one which is consistently faced by managers of domestic herds. Furthermore, studies of performance in natural populations assume independence among individuals but it is likely that many such samples also contain related individuals. Nevertheless, the fact remains that for pig breeders these three measures of performance are of utmost importance and associations between any or all of them and genotypes may be beneficial to the breeding programme.

Correlations between individual heterozygosity and components of fitness have been reported in many groups of organisms (reviewed in Mitton \& Grant, 1984; Allendorf \& Leary, 1986; Ledig, 1986; Zouros \& Foltz, 1987; Mitton, 1993a) but the modern management of pigs minimizes the probability of detecting correlations between heterozygosity and performance. Numerous studies have reported that stress enhances correlations between heterozygosity and components of fitness (Koehn \& Shumway, 1982; Rodhouse \& Gaffney, 1984; Diehl, 1988; Gentili \& Beaumont, 1988; Scott \& Koehn, 1990; Teska et al., $1990)$ but these pigs are raised under optimal conditions with unlimited food.

The loci monitored in this study were heterogeneous in their associations with IN and GR. Both $6 P G D$ and $G 6 P D$ had numerous statistically significant associations with FC and GR. In contrast to these loci, PGI and $P A$ exhibited no associations with either IN or GR. This heterogeneity in pattern of association is particularly interesting for $6 P G D$ and $P G I$, which are approximately $8.5 \mathrm{cM}$ apart on chromosome 15 . In two of the four population samples these loci are in linkage disequilibrium and yet the selection of breeding individuals influenced the genotypic distributions at $6 P G D$ but not at PGI. Similarly, the effects of heterozygosity on growth in Mulinia lateralis were examined with two 
pairs of linked loci, each with approximately 10 per cent recombination (Koehn et al., 1988). In each pair, one locus had a strong effect on growth rate, while the linked locus had no effect. This heterogeneity suggests that all allozyme loci may not be neutral markers characterizing large blocks of chromosomes.

The results presented here, together with previous studies (Mitton, 1993a,b), suggest that at least some protein polymorphisms contribute to the phenomena of heterosis and inbreeding depression. Similarly, comprehensive studies of enzyme kinetics and components of fitness reveal substantial influences of enzyme polymorphisms on physiological variation (see Garland \& Carter, 1994 for a comprehensive review) in the blue mussel, Mytilus edulis (Koehn et al., 1980; Hilbish \& Koehn, 1985), the killifish, Fundulus heteroclitus (Powers et al., 1991, 1993) and butterflies of the genus Colias (Watt et al., 1986; Carter \& Watt, 1988; Watt, 1992). Together these results suggest that some enzyme polymorphisms could be useful in the breeding programmes of domesticated species.

\section{References}

ALLENDORF, F. W. AND LEARY, R. F. 1986. Heterozygosity and fitness in natural populations of animals. In: Soulé, M. E. (ed.) Conversion Biology: The Science of Scarcity and Diversity, pp. 57-76. Sinauer Associates, Sunderland, MA.

BEARDMORE, J. A. AND SHAM1, S. A. 1979. Heterozygosity and the optimum phenotype under stabilizing selection. Aquilo. Ser. Zool., 20, 100-110.

BENGTSSON, S. AND SANDBERG, K. 1973. A method for simultaneous electrophoresis of four horse red cell enzyme systems. Anim. Blood Groups Biochem. Genet., 4, 83-87.

CARTER, P. A. AND WATT, w. B. 1988. Adaptation at specific loci. V. Metabolically adjacent enzyme loci may have very distinct experiences of selective pressures. Genetics, 119, 913-924.

CLEGG, M. T. AND ALLARD, R. w. 1973. Viability versus fecundity selection in the slender wild oat, Avena barbata L. Science, 181, 667-668.

ClEGG, M. T., KAHLER, A. L. AND ALLARD, R. W. 1978. Estimation of life cycle components of selection in an experimental plant garden. Genetics, 89, 765-791.

COTHRAN, E. G., CHESSER, R., SMITH, M. H. AND JOHNS, P. E. 1983. Influences of genetic variability and maternal factors on fetal growth in white-tailed deer. Evolution, 37, 282-291.

DANZMANN, R. G., FERGUSON, M. M. AND ALLENDORF, F. W. 1987. Heterozygosity and oxygen-consumption rates as predictors of growth and developmental rate in rainbow trout. Physiol. Zool., 60, 211-220.

DARWIN, C. 1859. The Origin of Species by Means of Natural Selection. John Murray, London.

DIEHL, w. J. 1988. Genetics of carbohydrate metabolism and growth in Eisenia foetida (Oligochaeta: Lumbricidae). Heredity, 61, 379-387.
DIEHL, W. J., GAFFNEY, P. M. AND KOEHN, R. K. 1986. Physiological and genetic aspects of growth in the mussel Mytilus edulis. I. Oxygen consumption, growth and weight loss. Physiol. Zool., 59, 201-211.

DIEHL, W. J., GAFFNEY, P. M., McDONALD, J. H. AND KOEHN, R. K. 1985. Relationship between weight standardized oxygen consumption and multiple-locus heterozygosity in the marine mussel Mytilus edulis L. (Mollusca). In: Gibbs, P. (ed.) Proceedings of the 19th European Marine Biology Symposium, pp. 531-536. Cambridge University Press, Cambridge.

ECHARD, G. 1984. The gene map of the pig (Sus scrofa domestica L.). In: O’Brien, S. J. (ed.) Genetic Maps 1984: A Compilation of Linkage and Restriction Maps of Genetically Studied Organisms, vol. 3, pp. 392-395. Cold Spring Harbor Laboratory, Cold Spring Harbor, NY.

FISHER, R. A. 1930. The Genetical Theory of Natural Selection. Oxford University Press, Oxford.

GAHNE, B., JUNEJA, R. K. AND GROLMUS, J. 1977. Horizontal polyacrylamide gradient gel electrophoresis for the simultaneous phenotyping of transferrin, post transferrin, albumin, and post albumin in the blood plasma of cattle. Anim. Blood Groups Biochem. Genet., 8, 127-137.

GARLAND, T. AND CARTER, P. A. 1994. Evolutionary physiology. Ann. Rev. Physiol., 56, 579-621.

GARTON, D. w. 1984. Relationship between multiple locus heterozygosity and physiological energetics of growth in the estuarine gastropod Thais haemastoma. Physiol. Zool., 57, 530-543.

GARTON, D. W., KOEHN, R. K. AND SCOTT, T. M. 1984. Multiple-locus heterozygosity and the physiological energetics of growth in the coot clam, Mulinia lateralis, from a natural population. Genetics, 108, 445-455.

GENTILI, M. R. AND BEAUMONT, A. R. 1988. Environmental stress, heterozygosity and growth rate in Mytilus edulis. J. Exp. Mar. Biol. Ecol., 120, 145-153.

GREEN, R. H., SINGH, S. M., HICKS, B. AND McCUAIG, J. M. 1983. An arctic intertidal population of Macoma balthica (Mollusca, Pelecypoda): genotypic and phenotypic components of population structure. Can. J. Fish. Aquat. Sci., 4, 1360-1371.

HALDANE, J. B. S. 1932. The Causes of Evolution. Longmans, London.

HAWKINS, A. J. S., BAYNE, B. L. AND DAY, A. J. 1986. Protein turnover, physiological energetics and heterozygosity in the blue mussel, Mytilus edulis: the basis of variable agespecific growth. Proc. R. Soc. Lond. B, 229, 161-176.

HAWKINS, A. J. S., BAYNE, B. L., DAY, A. J., RUSIN, J. AND WORRALL, C. M. 1989. Genotype-dependent interrelations between energy metabolism, protein metabolism and fitness. In: Ryland, J. S. and Tyler, P. A. (eds) Reproduction, Genetics and Distribution of Marine Organisms, pp. 283-292. Olsen and Olsen, Predensborg, Denmark.

HILBISH, T. J. AND KOEHN, R. K. 1985. Dominance in physiological phenotypes and fitness at an enzyme locus. Science, 229, 52-54.

KOEHN, R. K., DIEHL, w. J. AND SCOTT, T. M. 1988. The differential contribution by individual enzymes of glycolysis and protein catabolism to the relationship between hetero- 
zygosity and growth rate in the coot clam, Mulinia lateralis. Genetics, 118, 121-130.

KOEHN, R. K. AND GAFFNEY, P. M. 1984. Genetic heterozygosity and growth rate in Mytilus edulis. Mar. Biol., 82, 1-7.

KOEHN, R. K., MILKMAN, R. AND MITTON, J. B. 1976. Population genetics of marine pelecypods. IV. Selection, migration and genetic differentiation in the blue mussel Mytilus edulis. Evolution, 30, 2-32.

KOEHN, R. K., NEWELL, R. J. E. AND IMMERMAN, F. 1980. Maintenance of an aminopeptidase allele frequency cline by natural selection. Proc. Natl. Acad. Sci. U.S.A., 77, 5385-5389.

KOEHN, R. K. AND SHUMWAY, S. E. 1982. A genetic/physiological explanation for differential growth rate among individuals of the American oyster, Crassostrea virginica (Gmelin). Mar. Biol. Lett., 3, 35-42.

LEDIG, F. T. 1986. Heterozygosity, heterosis and fitness in outbreeding plants. In: Soulé, M. E. (ed.) Conservation Biology: The Science of Scarcity and Diversity, pp. 77-104. Sinauer Associates, Sunderland, MA.

LERner, I. M. 1954. Genetic Homeostasis. Oliver \& Boyd, Edinburgh.

MITTON, J. B. 1989. Physiological and demographic variation associated with allozyme variation. In: Soltis, D. and Soltis, P. (eds) Isozymes in Plants, pp. 127-145. Dioscorides Press, Portland, OR.

MiTTON, J. B. 1993a. Theory and data pertinent to the relationship between heterozygosity and fitness. In: Thornhill, N. (ed.) The Natural History of Inbreeding and Outbreeding, pp. 17-41. University of Chicago Press, Chicago.

MITTON, J. B. 1993b. Enzyme heterozygosity, metabolism and developmental stability. Genetica, 89, 47-65.

MITTON, J. B., CAREY, C. AND KOCHER, T. D. 1986. The relation of enzyme heterozygosity to standard and active oxygen consumption and body size of tiger salamanders, Ambystoma tigrinum. Physiol. Zool., 59, 574-582.

MITTON, J. B. AND GRANT, M. C. 1980. Observations on the ecology and evolution of quaking aspen, Populus tremuloides, in the Colorado Front Range. Am. J. Bot., 67, 202-209.

MITTON, J. B. AND GRANT, M. C. 1984. Associations among protein heterozygosity, growth rate and developmental homeostasis. Ann. Rev. Ecol. Syst., 15, 479-499.

MITTON, J. B. AND KOEHN, R. K. 1975. Genetic organization and adaptive response of allozymes to ecological variables in Fundulus heteroclitus. Genetics, 79, 97-111.

MITTON, J. B. AND PIERCE, B. A. 1980. The distribution of individual heterozygosity in natural populations. Genetics, 95, 1043-1054.

MITTON, J. B., SCHUSTER, W. S. F., COTHRAN, E. G. AND DEFRIES, J. 1993. The correlation in heterozygosity between parents and their offspring. Heredity, 71, 59-63.

PIERCE, B. A. AND MITTON, J. B. 1982. Allozyme heterozygosity and growth in the tiger salamander, Ambystoma tigrinum. J. Hered., 73, 250-253.

POWERS, D. A., LAUERMAN, T., CRAWFORD, D. AND DIMICHELE, L. 1991. Genetic mechanisms for adapting to a changing environment. Ann. Rev. Genet., 25, 629-659.

POWERS, D. A., SMITH, M., GONZALEZ-VILLASENOR, I., DIMICHELE, L., CRAWFORD, D., BERNARD1, G. AND LAUERMAN, T. 1993. A multi- disciplinary approach to the selectionist/neutralist controversy using the model teleost Fundulus heteroclitus. Oxford Surv. Evol. Biol., 8.

RASMUSSEN, B. A. 1983. Isozymes in swine breeding. Isozymes: Curr. Top. Biol. Med. Res., 11, 249-268.

RODHOUSE, P. G. AND GAFFNEY, P. M. 1984. Effect of heterozygosity on metabolism during starvation in the American oyster Crassostrea virginica. Mar. Biol., 80, 179-188.

SCOTT, T. M. AND KOEHN, R. K. 1990. The effect of environmental stress on the relationship of heterozygosity to growth rate in the coot clam Mulinia lateralis (Say). J. Exp. Mar. Biol. Ecol., 135, 109-116.

SiNGH, s. M. 1982. Enzyme heterozygosity associated with growth at different developmental stages in oysters. Can. J. Genet. Cytol., 24, 451-458.

SOKAL, R. R. AND ROHLF, F. J. 1981. Biometry, 2nd edn. W. H. Freeman and Co., San Francisco.

SPIESS, E. B. 1977. Genes in Populations. John Wiley, New York.

TANAKA, K., KUROSAWA, Y., KUROKAWA, K. AND OISHI, T. 1980. Genetic polymorphism of erythrocyte esterase-D in pigs. Anim. Blood. Groups Biochem. Genet., 11, 193-197.

TESKA, w. R., SMITH, M. H. AND NOVAK, J. M. 1990. Food quality, heterozygosity and fitness correlated in Peromyscus polionotus. Evolution, 44, 1318-1325.

WATT, w. B. 1983. Adaptation at specific loci. II. Demographic and biochemical elements in the maintenance of the Colias PGI polymorphism. Genetics, 103, 691-724.

WATT, W. B. 1992. Eggs, enzymes and evolution-natural genetic variants change insect fecundity. Proc. Natl. Acad. Sci. U.S.A., 89, 10608-10612.

WATT, w. B., CARTER, P. A. AND DONOHUe, K. 1986. Females' choice of 'good genotypes' as mates is promoted by an insect mating system. Science, 233, 1187-1190.

WATT, w. B., CASSIN, R. C. AND SWAN, M. s. 1983. Adaptation a specific loci. III. Field behavior and survivorship differences among Colias PGI genotypes are predictable from in vitro biochemistry. Genetics, 103, 725-739.

WEBSTER, T. P. 1973. Adaptive linkage disequilibrium between two esterase loci of a salamander. Proc. Natl. Acad. Sci. U.S.A., 70, 1156-1160.

WORKMAN, P. L. AND NISWANDER, J. D. 1970. Population studies on Southwestern Indian tribes. II. Local differentiation in the Papago. Am. J. Hum. Genet., 22, 24-49.

WRIGHT, s. 1977. Evolution and the Genetics of Populations, vol. 3. Experimental Results and Evolutionary Deductions. The University of Chicago Press, Chicago.

zouros, E. AND FOLTZ, D. w. 1987. The use of allelic isozyme variation for the study of heterosis. In: Rattazzi, M. C., Scandalios, J. G. and Whitt, G. S. (eds) Isozymes: Current Topics in Biological and Medical Research, vol. 13, pp. 1-59. Alan R. Liss, New York.

zouros, E., SINGH, S. M., FOLTZ, D. W. AND MALlET, A. L. 1983. Postsettlement viability in the American oyster (Crassostrea virginica): an overdominant phenotype. Genet. Res., 41, $259-270$.

ZOUROS, E., SINGH, S. M. AND MILES, H. E. 1980. Growth rate in oysters: an overdominant phenotype and possible explanations. Evolution, 34, 856-867. 